\title{
Correlation of CD4:CD8 ratio and tumour necrosis factor (TNF) $\alpha$ levels in induced sputum with bronchoalveolar lavage fluid in pulmonary sarcoidosis
}

Yuben P Moodley, Trevor Dorasamy, Salosh Venketasamy, Vincent Naicker, Umesh G Lalloo

\begin{abstract}
Background-An increased CD4:CD8 lymphocyte ratio and raised cytokine levels in bronchoalveolar lavage (BAL) fluid are characteristic of pulmonary sarcoidosis. Sputum induction has been used as a non-invasive tool for investigating the airways and may be useful in investigating inflammation in patients with sarcoidosis in whom endobronchial, peribronchial, and parenchymal inflammation is present. This study aimed to correlate the total and differential cell counts, CD4:CD8 ratio, and tumour necrosis factor (TNF) $\alpha$ levels between induced sputum and BAL fluid in patients with pulmonary sarcoidosis.

Methods-Fourteen patients with newly diagnosed biopsy proven sarcoidosis and six healthy controls were investigated. Sputum induction and BAL was carried out at the initial visit and repeated following six months of treatment with oral prednisone.

Results-There was no correlation of differential cell counts between induced sputum and BAL fluid. The CD4:CD8 ratio in induced sputum correlated strongly with that in BAL fluid (5.5 (0.4:1) versus $4.4(0.2: 1) ; r=0.8, p<0.001)$ and the fall in the ratio following six months of treatment in sputum paralleled that in BAL fluid (3.4 (0.2:1) versus 2.4 (0.2:1)). The TNF $\alpha$ levels in sputum also correlated with levels in the BAL fluid (11.9 (1.5) pg/ $\mathrm{ml}$ versus $17.6(2.7) \mathrm{pg} / \mathrm{ml} ; r=0.8$, $p<0.001)$. The fall in sputum TNFa levels following six months of treatment paralleled the fall in BAL fluid levels (6.7 (0.9) $\mathrm{pg} / \mathrm{ml}$ versus 11.6 (1.3) $\mathrm{pg} / \mathrm{ml}$ ). Conclusions-The CD4:CD8 ratio and TNF $\alpha$ levels in induced sputum correlated with those in BAL fluid and paralleled changes with treatment. Induced sputum may therefore be a non-invasive surrogate for certain parameters in BAL fluid in patients with sarcoidosis.

(Thorax 2000;55:696-699)
\end{abstract}

Keywords: pulmonary sarcoidosis; CD4:CD8 ratio; tumour necrosis factor

Sarcoidosis is a multisystem granulomatous disorder of unknown aetiology that predomi- nantly affects the lung. ${ }^{1}$ An increased $\mathrm{T}$ lymphocyte CD4:CD8 ratio in bronchalveolar lavage (BAL) fluid is characteristic of sarcoidosis but not specific. ${ }^{2}$ There is controversy regarding the role of BAL fluid as a marker of disease activity although persistent abnormalities in chronic sarcoidosis may predict functional deterioration. ${ }^{2}$

Induction of sputum by inhalation of hypertonic saline has recently been developed as a method of sampling airway secretions. It is has been used to investigate inflammatory cells and mediators in normal subjects, asthmatic patients, ${ }^{3}$ and those with chronic obstructive pulmonary disease. ${ }^{4}$ Tumour necrosis factor (TNF) $\alpha$ levels are raised in the granulomatous inflammation in patients with sarcoidosis. ${ }^{5}$ The granulomatous inflammation in sarcoidosis is endobronchial, peribronchial, and parenchymal. ${ }^{6}$ We therefore hypothesised that the airway involvement in sarcoidosis makes this condition potentially amenable to investigation by sputum induction and that the cellularity, CD4:CD8 ratio, and analysis of $\mathrm{TNF} \alpha$ in the sol phase of induced sputum will correlate with BAL fluid.

The aims of this study therefore were to investigate the differential cell count, $\mathrm{CD} 4: \mathrm{CD} 8$ ratio, and $\mathrm{TNF} \alpha$ levels in induced sputum and to correlate these with BAL fluid at baseline and after six months of treatment with oral prednisone in patients with sarcoidosis.

\section{Methods}

SUBJECTS

Seventeen consecutive patients with newly diagnosed biopsy proven pulmonary sarcoidosis were recruited from the Respiratory Unit of King Edward VIII Hospital, a major teaching hospital in Durban, South Africa. Of these, 14 patients (seven men) of mean (SD) age 40.6 (1.8) years were able to produce an adequate sputum sample at baseline and following six months of treatment and comprised the study cohort. Patients were treated with an initial dose of prednisone of $40 \mathrm{mg}$ /day orally for six weeks, tapering to $10 \mathrm{mg} /$ day within six months.

Healthy controls comprised 12 nonsmoking, non-atopic volunteers of mean (SD) age 41 (2.8) years, matched for age, sex, and race who were able to produce adequate sputum samples following sputum induction. They had had no respiratory tract illnesses in 
the six weeks preceding the study. Their forced expiratory volume in one second $\left(\mathrm{FEV}_{1}\right)$ was 98 (8)\% predicted.

STUDY PROTOCOL

The ethics committee of the University of Natal approved the study and signed informed consent was obtained from all patients before entry into the study. Spirometric tests, serum angiotensin converting enzyme levels, liver function, urea and electrolytes, full blood count, serum calcium levels, 24 hour urinary calcium excretion, chest radiography, and high resolution computed tomographic (HRCT) scan of the chest was performed on all subjects. The HRCT scan was done as part of a larger study correlating lung function and radiological features in sarcoidosis with exhaled nitric oxide levels in these subjects. Induced sputum was obtained at baseline and four days later to test for reproducibility of the differential cell counts. BAL was performed four days later. Induced sputum and BAL were repeated six months after the baseline study.

\section{SPUTUM INDUCTION}

Sputum induction was performed according to the standard procedure described elsewhere. ${ }^{4}$ The subjects were instructed to rinse their mouth thoroughly with water after inhalation of $200 \mu \mathrm{g}$ aerosolised salbutamol. They then inhaled 3\% saline at room temperature, nebulised for 20 minutes via an ultrasonic nebuliser (DeVilbiss 99; Heston, UK) set at maximum output $(4.5 \mathrm{ml} / \mathrm{min})$.

Subjects were encouraged to cough at five minutes and then at three minute intervals into polypropylene pots. Saliva was initially expectorated into a separate container. Sputum plugs up to an approximate volume of $3 \mathrm{ml}$ were selected.

PROCESSING OF SPUTUM SAMPLES

A $1 \mathrm{ml}$ sample of sputum was spun at 60000 rpm for 10 minutes and the supernatant was stored at $-70^{\circ} \mathrm{C}$ for cytokine analysis. The rest of the sputum sample was diluted with $2 \mathrm{ml}$ Hank's balanced salt solution (HBSS) containing $1 \%$ dithioreitol (DTT) (Sigma Chemicals, Poole, UK) and gently vortexed until homogenous. The cell pellet was resuspended in $2 \mathrm{ml}$ HBSS. Total cell counts were determined by a haemocytometer using a Kimura stain. Slides were prepared using a cytospin (Shandon, Runcorn, UK) and stained with May-GrunwaldGiemsa for differential cell counts. Two observers blinded to the patients' characteristics counted 400 cells. Differential cell counts were expressed as a percentage of lower airway cells.

One $\mathrm{ml}$ of the suspension was processed for flow cytometry. The suspension of sputum cells in DTT was layered across a density gradient medium (Histopaque 1077, Sigma) and cytocentrifuged at $1000 \mathrm{rpm}$ for 10 minutes. The cell pellet obtained was resuspended in $2 \mathrm{ml} \mathrm{HBSS}$ and incubated with $2 \mathrm{ml}$ $10 \%$ bovine serum albumin at room temperature for 20 minutes to reduce non-specific binding. This suspension was then centrifuged at $3000 \mathrm{rpm}$ for two minutes and the cell pellet was resuspended in HBSS. Pairs of monoclonal antibodies CD3/CD19 ( $\mathrm{T}$ and B cells), CD3/CD4 ( $\mathrm{T}$ helper cells), CD4/CD25 (activated helper $\mathrm{T}$ cells), CD8/CD25 (activated suppressor $\mathrm{T}$ cells), and CD3/CD8 (suppressor $\mathrm{T}$ cells) (Sigma Diagnostics, Poole, UK) were then added to the suspension and incubated for 30 minutes. The suspension was then subjected to flow cytometry to determine the CD4 and CD8 lymphocyte subsets. ${ }^{7}$

BRONCHOSCOPY AND BAL

An Olympus bronchoscope FIT20D (Tokyo, Japan) was inserted and wedged in the right middle lobe under adequate local anaesthesia and sedation with midazolam. A segment was lavaged using three $60 \mathrm{ml}$ aliquots of saline. The BAL fluid samples were analysed for total and differential cell counts, $\mathrm{TNF} \alpha$ levels, and flow cytometry to measure CD4:CD8 lymphocyte counts.

PROCESSING OF BAL FLUID

The pooled BAL fluid specimen was passed through sterile nylon gauze. Aliquots of $2 \mathrm{ml}$ lavage fluid were cytocentrifuged at $1000 \mathrm{rpm}$ for 10 minutes. The supernatant was stored for the measurement of TNF $\alpha$ levels and the cell pellet was resuspended in HBSS. A concentration of $1 \times 10^{5}$ cells $/ \mathrm{ml}$ was prepared and a cytospin slide preparation made (Shandon) and stained with May-Grunwald-Giemsa. Two observers blinded to the patients' characteristics counted 400 cells to determine the differential cell count.

A further $2 \mathrm{ml}$ of lavage fluid was resuspended in HBSS and layered onto a density gradient medium (Histopague-1077, Sigma Diagnostics, UK) and cytocentrifuged at $600 \mathrm{~g}$ for 10 minutes. The cell pellet was then resuspended in HBSS and incubated with $10 \%$ bovine serum albumin (Sigma) for 20 minutes. As for sputum, pairs of monoclonal antibodies to CD4 and CD8 lymphocytes were then added to the suspension and incubated for 30 minutes after which flow cytometry was performed.

FLOW CYTOMETRY

Flow cytometry was performed using an EpicProfile-II flow cytometer (Hialeah, Florida, USA) that detects lymphocytes by fluorescence. The fluorescence was backgated to show that lymphocytes in the sputum had similar physical properties (forward and side scatter, size and granularity) to lymphocytes in BAL fluid. Lymphocytes lie in a cigar-shaped cluster with a low wide scatter and more elongated forward scatter than lymphocytes in the blood. To enhance the number of lymphocytes for analysis, an acquisition gate was set using the lower third of the side scatter field. The analysis gate was broad in order to exclude non-lymphocytic cells. Results were expressed as percentage of the cells detected by fluorescence and not as a percentage of the gate because of contaminating debris in the sputum. A minimum of 400 lymphocytes detected on the CD3/CD19 panel was regarded as acceptable because it is the amount used in immunohistochemistry. ${ }^{7}$ 
Table 1 Differential cell counts in healthy controls and patients with sarcoidosis at baseline and following six months of treatment with oral prednisone

\begin{tabular}{|c|c|c|c|c|c|c|c|c|c|c|}
\hline & \multicolumn{2}{|c|}{ Total cells $\left(\times 10^{6} / \mathrm{ml}\right)$} & \multicolumn{2}{|c|}{ Macrophages (\%) } & \multicolumn{2}{|c|}{ Lymphocytes (\%) } & \multicolumn{2}{|c|}{ Neutrophils (\%) } & \multicolumn{2}{|c|}{ Eosinophils (\%) } \\
\hline & Baseline & $\begin{array}{l}6 \text { months } \\
\text { treatment }\end{array}$ & Baseline & $\begin{array}{l}6 \text { months } \\
\text { treatment }\end{array}$ & Baseline & $\begin{array}{l}6 \text { months } \\
\text { treatment }\end{array}$ & Baseline & $\begin{array}{l}6 \text { months } \\
\text { treatment }\end{array}$ & Baseline & $\begin{array}{l}6 \text { months } \\
\text { treatment }\end{array}$ \\
\hline Sputum control & $6.2(2.2)$ & & $75.2(8.6)$ & & $1.8(0.7)$ & & $17.8(5.1)$ & & $0.5(0.2)$ & \\
\hline Sputum sarcoidosis & $9.4(1.5)^{\star}$ & $7.7(0.5)$ & $70.3(3.1)$ & $76.0(1.5)$ & $17.9(2.5)^{\star}$ & $12.7(1.3)$ & $12.3(5.0)$ & $11.4(1.1)$ & $0.6(0.1)$ & $0.4(0.2)$ \\
\hline BAL fluid control & $7.0(1.5)$ & & $89.5(3.8)$ & & $1.7(0.7)$ & & $0.8(0.2)$ & & $0.5(0.2)$ & \\
\hline BAL fluid sarcoidosis & $14.5(2.4)^{\star}$ & $10.9(0.6)$ & $79.1(3.3)$ & $85.9(1.8)$ & $25.6(3.4)^{\star}$ & $12.4(1.8)^{\star \star}$ & $1.2(0.9)$ & $2.2(0.4)^{\star \star}$ & $0.4(0.2)$ & $0.3(0.3)$ \\
\hline
\end{tabular}

${ }^{\star} \mathrm{p}<0.001$ sarcoidosis versus healthy controls $(t$ test).

$\star^{\star} \mathrm{p}<0.001$ six months of treatment versus baseline.

TNF $\alpha$ ASSAY

The TNF $\alpha$ concentrations were measured using an enzyme linked immunosorbent assay (ELISA) kit obtained from Genzyme (Cambridge, Massachusetts, USA). ${ }^{4}$ Briefly, the kit contained 96-well microtitre plates precoated with bovine serum albumin. Samples were added to the wells and incubated with monclonal anti-TNF $\alpha$ antibodies for four hours. The optical density of the plate was then read using a plate photometer. The detection limit of the assay was $0.5 \mathrm{pg} / \mathrm{ml}$.

\section{STATISTICAL ANALYSIS}

Cell counts were expressed $\times 10^{6} / \mathrm{ml}$ and differential cell counts were expressed as a percentage of the mean (SE). The intraclass correlation coefficient was used to evaluate the reproducibility of differential cell counts. Pearson's correlation coefficients were used to establish correlations between the individual cellularities, CD4:CD8 ratio, and $\mathrm{TNF} \alpha$ levels in sputum and BAL fluid. An $r$ value of $>0.7$ was regarded as acceptable and a $p$ value of $<0.05$ was regarded as significant. The $95 \%$ confidence intervals (CI) for the CD4:CD8 ratios and $\mathrm{TNF} \alpha$ levels are also presented.

\section{Results}

The total and differential cell counts in induced sputum in patients with sarcoidosis between the baseline visit and the second visit four days later were reproducible: total cell count $(r=0.8)$, macrophages $(r=0.8)$, lymphocytes $(r=0.8)$, neutrophils $(r=0.7)$, and eosinophils $(r=0.8)$ (intraclass correlation coefficients).

The differential cell counts in induced sputum and BAL fluid of healthy controls and patients with sarcoidosis at baseline are shown in table 1 . The total cell count, lymphocytes, $\mathrm{CD} 4: \mathrm{CD} 8$ ratio, and $\mathrm{TNF} \alpha$ levels were significantly higher in induced sputum and BAL fluid of patients with sarcoidosis than of healthy controls.

There was no correlation between the differential cell counts in sputum and BAL fluid: macrophages, $r>0.07, \mathrm{p}>0.8$; lymphocytes, $r>0.2, \mathrm{p}>0.5$; and neutrophils $r>0.4, \mathrm{p}>0.4$. The CD4:CD8 ratio in induced sputum correlated strongly with that in BAL fluid: 5.5 $(0.4: 1)(95 \%$ CI 3.5 to 6.4$)$ versus $4.4(0.2: 1)$ (95\% CI 3.2 to 4.9 ), $r>0.8, \mathrm{p}<0.001$. The fall in the ratio following six months of treatment with oral prednisone in sputum paralleled the fall in BAL fluid: $3.4(0.2: 1)(95 \%$ CI 2.1 to 3.7 ) versus $2.4(0.2: 1)$ (95\% CI 2.1 to 2.7$)$, $r>0.8, \mathrm{p}<0.001$. The $\mathrm{TNF} \alpha$ levels in sputum also correlated with levels in the BAL fluid: 11.9 (1.5) $\mathrm{pg} / \mathrm{ml}$ (95\% CI 9 to 16$)$ versus 17.6 (2.7) $\mathrm{pg} / \mathrm{ml}(95 \%$ CI 14 to 25$), r>0.8, \mathrm{p}$ $<0.001$. The fall in TNF $\alpha$ levels in the sputum following six months of treatment paralleled the fall in BAL fluid: $6.7(0.9) \mathrm{pg} / \mathrm{ml}(95 \% \mathrm{CI}$ 3 to 8 ) versus $11.6(1.3) \mathrm{pg} / \mathrm{ml}(95 \%$ CI $5-17)$, $r>0.8, \mathrm{p}<0.001$.

There was no correlation between the CD4:CD8 ratio and $\mathrm{TNF} \alpha$ levels in induced sputum and BAL fluid and other markers of disease activity.

\section{Discussion}

This study has shown that the cellularity in induced sputum of patients with sarcoidosis is reproducible. A strong correlation was found between the CD4:CD8 ratio and $\mathrm{TNF} \alpha$ levels in induced sputum and BAL fluid at baseline and following six months of treatment with oral prednisone. The fall in the CD4:CD8 ratio and $\mathrm{TNF} \alpha$ levels in BAL fluid following prednisone treatment was paralleled by that in induced sputum. There was, however, a poor correlation of individual cell subsets between sputum and BAL fluid.

The total cell counts in BAL fluid in this study were higher than those reported in some studies $^{2}$ but lower than in others. ${ }^{8}$ These inconsistencies are probably due to differences in processing techniques of the BAL fluid specimen and cytospin preparations. ${ }^{9}$ The differential cell counts in this study are in agreement with most studies. ${ }^{28}$ The lack of correlation between macrophage and lymphocyte counts in induced sputum and BAL fluid is probably due to the fact that the BAL fluid sample was taken from a more distal compartment of the lung than induced sputum. ${ }^{10}$

The strong correlation of the CD4:CD8 ratio in induced sputum and BAL fluid in patients with sarcoidosis may reflect inflammation in both the proximal and distal parts of the lung. There was a significant increase in $\mathrm{TNF} \alpha$ levels in induced sputum and BAL fluid in patients with sarcoidosis compared with healthy controls, reflecting the increased synthesis of this cytokine in active pulmonary sarcoidosis which confirms previous observations. $^{5}$

The CD 4:CD8 ratio and $\mathrm{TNF} \alpha$ levels in induced sputum and BAL fluid did not correlate with other conventional parameters of disease activity such as serum angiotensin converting enzyme levels and forced expiratory 
volume in one second $\left(\mathrm{FEV}_{1}\right)$, probably because the various parameters measure different aspects of the disease process.

This study has shown that the CD4:CD8 ratio and $\mathrm{TNF} \alpha$ levels in induced sputum correlated with those in the BAL fluid in patients with pulmonary sarcoidosis, although there was no correlation with the total and differential cell counts. Induced sputum may therefore be a non-invasive surrogate for certain parameters in BAL fluid in patients with sarcoidosis.

This study was supported by a research grant from the South African Medical Research Council.

1 Scadding JG, Mitchell DN. Sarcoidosis. 2nd edn. London: Chapman and Hall, 1985.

2 Neville E, Walker AN, James DG. Prognostic factors predicting the outcome of sarcoidosis: an analysis of 818 predients. $Q \mathcal{F}$ Med 1983;208:525-33.
3 Pin I, Gibson PG, Kolendowics R, et al. Use of induced sputum cell counts to investigate airway inflammation in asthma. Thorax 1992;47:25-9.

4 Keatings VM, Collins PD, Scott DM, et al. Differences in interleukin-8 and tumor necrosis factor $\alpha$ in induced sputum from patients with chronic obstructive pulmonary disease or asthma. Am F Respir Crit Care Med 1996;153: $530-4$.

5 Peuringer RJ, Shwartz RA, Dayton GS, et al. The relationship between alveolar macrophage, TNF, IL-1 and PGE release, alveolitis and disease severity in sarcoidosis. Chest 1993;103:832-8.

6 Rosen Y, Vuletin JC, Pertschuk LP, et al. Sarcoidosis from the pathologists vantage point. Pathol Annu 1979;14:4058.

7 Kidney JC, Wong A, Efthimiadis A, et al. Elevated B cells in sputum of asthmatics: close correlation with eosinophils. Am f Respir Crit Care Med 1996;153:540-4.

8 Drent $M$, van Nierop MF, Gerritsen FA, et al. A computer program using BAL fluid analysis results as a diagnostic tool in interstitial lung diseases. Am $\mathcal{F}$ Respir Crit Care Med 1996;153:736-41.

9 Reynolds HY. Bronchoalveolar lavage - state of the art. Am Rev Respir Dis 1987;135:250-63.

10 Lensmar C, Elmberger G, Sandgren P, et al. Leukocyte counts and macrophage phenotypes in induced sputum and bronchoalveolar lavage fluid from normal subjects. Eur Respir f 1999;12:595-600. 